IZA DP No. 6703

Differences in Quality of Life Estimates Using Rents and Home Values

John V. Winters

July 2012 


\title{
Differences in Quality of Life Estimates Using Rents and Home Values
}

\author{
John V. Winters \\ University of Cincinnati \\ and IZA
}

\author{
Discussion Paper No. 6703 \\ July 2012
}

IZA
P.O. Box 7240
53072 Bonn
Germany

Phone: +49-228-3894-0

Fax: +49-228-3894-180

E-mail: iza@iza.org

\begin{abstract}
Any opinions expressed here are those of the author(s) and not those of IZA. Research published in this series may include views on policy, but the institute itself takes no institutional policy positions.

The Institute for the Study of Labor (IZA) in Bonn is a local and virtual international research center and a place of communication between science, politics and business. IZA is an independent nonprofit organization supported by Deutsche Post Foundation. The center is associated with the University of Bonn and offers a stimulating research environment through its international network, workshops and conferences, data service, project support, research visits and doctoral program. IZA engages in (i) original and internationally competitive research in all fields of labor economics, (ii) development of policy concepts, and (iii) dissemination of research results and concepts to the interested public.
\end{abstract}

IZA Discussion Papers often represent preliminary work and are circulated to encourage discussion. Citation of such a paper should account for its provisional character. A revised version may be available directly from the author. 


\section{ABSTRACT}

\section{Differences in Quality of Life Estimates Using Rents and Home Values ${ }^{\star}$}

Quality of life differences across areas can be measured by differences in "real wages", where real wages are computed as nominal wages adjusted for the cost of living. Computing cost of living differences involves several important issues, including how housing prices should be measured. Previous researchers typically have used some combination of rental payments and homeowner housing values, but housing values are forward-looking and may not reflect current user costs. This paper examines differences in quality of life estimates for U.S. metropolitan areas using, alternatively, rents and housing values. We find that the two measures of quality of life are highly correlated. Value-based estimates, however, are considerably more dispersed than rent-based estimates, likely because of the recent housing bubble and because housing values often provide an imperfect measure of the present user cost of housing. Researchers should be cautious in using housing values to construct quality of life estimates.

\section{JEL Classification: R13, R21, R23}

Keywords: quality of life, amenities, rents, housing, wages

Corresponding author:

John V. Winters

Department of Economics

University of Cincinnati

P.O. Box 210371

Cincinnati, OH 45221

USA

E-mail: winterjh@ucmail.uc.edu

\footnotetext{
* The author would like to thank Barry Hirsch, three anonymous referees, and session participants at the 2009 annual meeting of the Southern Economic Association for helpful comments. Any errors or omissions are solely the responsibility of the author.
} 


\section{Introduction}

Researchers, policymakers, and the general public are all interested in differences in the quality of life across areas. Quality of life differences affect individual welfare and have been found to be an important driver of metropolitan population growth (Rappaport 2007, 2009). A number of popular publications have emerged that rank the quality of life across cities and states based on their observable characteristics. Following Rosen (1979) and Roback (1982), economists and other researchers have ranked the quality of life across areas based on compensating differentials in labor, housing, and consumption markets. ${ }^{1}$ In other words, the existence of a spatial equilibrium necessitates that workers accept lower "real wages" to live in nicer areas. Computing real wages requires estimating cost of living differences across areas, and doing so is one of the biggest challenges faced by quality of life researchers. Differences in the cost of living across areas are mostly attributable to differences in the cost of housing (Beeson and Eberts 1989), but are also at least partially attributable to differences in the prices of non-housing goods (Gabriel, Mattey, and Wascher 2003). There are two main issues in computing cost of living differences. The first is that good information on non-housing prices is not readily available for all areas. Researchers usually deal with this by either ignoring nonhousing prices altogether (e.g., Roback 1982; Blomquist, Berger and Hoehn 1988) or by inferring non-housing prices from housing prices when non-housing prices are not available (e.g., Shapiro 2006; Albouy 2008). ${ }^{2}$

The second major issue in computing cost of living differences is whether housing prices should be measured by rental payments, estimated homeowner user costs based on housing values, or both (Winters 2009). Most studies assume that the true user cost of housing can be

\footnotetext{
${ }^{1}$ Gabriel and Rosenthal (2004) also develop a method to rank the quality of the business environment across areas. ${ }^{2}$ Alternatively, Gyourko and Tracy (1991) treat non-housing prices as an amenity in wage and housing hedonic regressions.
} 
accurately measured by both housing rents and housing values and, therefore, measure housing prices using a weighted average of rental payments and homeowner values, with greater weight given to homeowner values. ${ }^{3}$ However, the recent housing bubble has caused rents and homeowner values to diverge considerably (Verbrugge 2008; Garner and Verbrugge 2009). Even absent a housing bubble, the ratio of housing values to rents is likely to differ across areas because of different expectations about the future growth of rents (Clark, 1995; Davis, Lehnert and Martin 2008). Rental payments reflect the actual current user cost of housing for a specific period of time. However, a house is an asset that yields a stream of future benefits to its owner. The value of a house is equal to the expected net present value of the future benefit stream it generates. Areas where rents are expected to grow more quickly over time should have a higher ratio of current values to current rents because the expected increase in future rental payments is capitalized into current housing values. Therefore, measuring the current user cost of housing using house values may be inappropriate for estimating the cost of living. Because of this the U.S. Bureau of Labor Statistics (BLS) measures housing prices solely by rents and not values in computing the Consumer Price Index (CPI). Winters (2009) also suggests that the relationship between wages and prices across metropolitan areas is consistent with the spatial equilibrium hypothesis when housing prices are measured by rents but not when housing prices are measured by housing values. Furthermore, Banzhaf and Farooque (2012) find that local public amenities and income levels are more highly correlated with rents than owner values. This paper suggests that quality of life estimates should base housing prices solely on rents and not on housing values.

\footnotetext{
${ }^{3}$ A few previous studies have also measured housing prices using either only rents or only housing values instead of a combination of the two, but no previous study has examined differences in quality of life rankings that result from measuring housing prices by only rents or only housing values.
} 
Using a framework similar to Rosen (1979) and Roback (1982), this paper computes quality of life estimates across metropolitan areas of the U.S. for the year 2007. The preferred estimates compute housing prices using quality-adjusted rents because rents reflect the current user cost of housing but housing values are based on the future stream of benefits provided by the house. For comparison, we also compute quality of life estimates for which housing prices are measured solely by housing values. The two measures of quality of life are very highly correlated, but value-based estimates are considerably more dispersed across areas than the rentbased estimates. That is, the value-based estimates report a higher implicit value of amenities in high amenity areas than do the rent-based estimates. This is likely due in large part to the dramatic growth in housing values prior to 2007. However, we also estimate quality of life values for 2000 and find that a similar relationship holds in that year, though to a much lesser extent. Value-based estimates are notably more dispersed than rent-based estimates. Rents are superior on theoretical grounds, and we argue that future researchers should use rents and not values when computing estimates of quality of life and amenity values.

The paper proceeds as follows. The next section presents the theoretical framework based on the seminal work of Rosen (1979) and Roback (1982). The third section discusses the empirical approach and data used in this study. A fourth section presents the results for the

quality of life estimates. A fifth section examines the effect of quality of life on changes in rents and housing values from 2000 to 2007 . A final section concludes.

\section{Theoretical Framework}

This section presents a simple model following Rosen (1979) and Roback (1982) that shows that differences in amenity values across cities can be computed from differences in real 
wages. Firms produce two goods, $X_{1}$ and $X_{2}$, according to constant returns to scale production functions using labor $(N)$, capital $(K)$, and land $(L)$ and subject to locational differences in productivity due to amenities $(Z): X_{i}=X_{i}(N, K, L ; Z)$. The marginal products of labor, capital, and land are all non-negative, but increases in amenities can either increase or decrease productivity. The price of capital is determined exogenously in the world market, while the prices of labor $(W)$ and land $\left(P_{L}\right)$ are determined competitively in local markets. In equilibrium, firms earn zero profits and the price of each good is equal to its unit cost of production $\left(C_{i}\right)$ :

$$
C_{i}\left(W, P_{L} ; Z\right)=P_{i}, \quad i=1,2 \text {. }
$$

Individual workers maximize their own utility subject to a budget constraint. Utility is a function of goods $X_{1}$ and $X_{2}$ and location-specific amenities: $U=U\left(X_{1}, X_{2} ; Z\right)$. Workers are mobile across areas, and in equilibrium utility for identical workers is equal across all areas. ${ }^{4}$ The indirect utility function can be represented as a function of wages and the prices of $X_{1}$ and $X_{2}$ given amenities:

$$
V=V\left(W, P_{1}, P_{2} ; Z\right)
$$

Taking the total differential of both sides of (2), setting $d V=0$ so that there are no differences in utility across areas, rearranging, and employing Roy's Identity yields a slight variant of the common equation used to estimate the implicit price of amenities:

$$
P_{Z} d Z=X_{1} d P_{1}+X_{2} d P_{2}-d W^{5}
$$

Dividing both sides of (3) by $W$ converts the equation to:

\footnotetext{
${ }^{4}$ Greenwood, Hunt, Rickman, and Treyz (1991) find that although a few areas may be out of equilibrium at a given point in time, spatial equilibrium is not an unreasonable assumption for the most part. Oswald and Wu (2010, 2011), however, find that subjective responses about individual well-being differ across the United States even after controlling for individual characteristics. This may reflect heterogeneous preferences for locations (Krupka and Donaldson 2007) or decreased responsiveness to area-specific demand shocks (Partridge, Rickman, Olfert and Ali 2012). This could affect our ability to accurately estimate implicit amenity prices and rank quality of life across areas.

${ }^{5}$ Alternatively, we could have defined the expenditure function and used Shephard's Lemma to obtain an equivalent result as in Albouy (2008).
} 


$$
\left(P_{Z} / W\right) d Z=\left(P_{1} X_{1} / W\right) d \ln P_{1}+\left(P_{2} X_{2} / W\right) d \ln P_{2}-d \ln W
$$

Equation (4) says that the implicit share of wages spent on amenity consumption in an area can be computed from logarithmic differences in real wages across areas, where real wages are equal to nominal wages, $W$, divided by the cost of living, $\boldsymbol{P}$. Logarithmic differences in nominal wages are represented by the $d \ln W$ term. Logarithmic differences in the cost of living are given by an expenditure share weighted average of the logarithmic differences in the prices of goods one and two. That is, $d \ln \boldsymbol{P}=\left(P_{1} X_{1} / W\right) d \ln P_{1}+\left(P_{2} X_{2} / W\right) d \ln P_{2}$. The implicit share of wages spent on amenity consumption is thus equal to the negative of log differences in real wages, i.e., $d \ln \boldsymbol{P}-d \ln W{ }^{6}$ To live in an area with nice amenities workers must accept lower real wages. ${ }^{7}$

\section{Empirical Framework and Data}

This study estimates quality of life values for metro areas in the U.S. from the negative of logarithmic differences in real wages. Most previous studies of quality of life differentials across areas try to separately estimate the effect of amenities on wages and housing prices and then aggregate the compensating differentials from these markets to estimate the value of the quality of life in each area. ${ }^{8}$ An important limitation to this approach is that important amenities are unlikely to be completely observed. This would cause the quality of life in areas with nice unobserved amenities to be understated. A further problem concerns how one should account for non-housing prices in this method. Should non-housing price differentials be treated as resulting

\footnotetext{
${ }^{6}$ If the real wage is $W / \boldsymbol{P}$, then the $\log$ of the real wage is $\ln W-\ln \boldsymbol{P}$.

${ }^{7}$ For non-workers, the implicit price to live in a high quality of life area depends only on the cost of living and not on wages. Thus we would expect retirees and other non-workers to be attracted to areas where amenity values are capitalized more into wages than prices (Chen and Rosenthal 2008).

${ }^{8}$ See Gyourko, Kahn and Tracy (1999) for a review of the literature on quality of life and amenity valuation. Stover and Leven (1992) also discuss a number of important issues related to estimating quality of life.
} 
from amenities as in Gabriel et al. (2003)? What if some of the differential in non-housing prices is due to things other than amenities, such as geographical remoteness? The real wage approach used in this paper does not rely on observed values of amenities and it provides a clear answer as to how non-housing prices should be treated. There are certainly limitations to the real wage approach as well ${ }^{9}$, but it is considered the preferred method for valuing amenities and quality of life in this paper. Similar approaches are also used in Kahn (1995), Albouy (2008), and others. ${ }^{10}$

This paper computes logarithmic differences in nominal wages and housing prices across metropolitan areas using microdata from the 2007 American Community Survey (ACS) and the 2000 Census, both of which are available from the IPUMS (Ruggles et al. 2008). In this study, the geographical unit of analysis is the Combined Statistical Area (CSA) where one exists and the Core Based Statistical Area (CBSA) for areas not part of a CSA. For ease of discussion, we usually just refer to these as metropolitan areas. We only consider CSA/CBSAs that are primarily metropolitan in nature and can be at least partially identified from the IPUMS data. Unfortunately, the IPUMS data do not allow identification of geographic areas with populations less than 100,000. Consequently, the lowest level of identifiable geography, the PUMA, often includes both metropolitan and non-metropolitan areas. We assign each PUMA to a metropolitan area if more than 50 percent of the population of the PUMA is contained within the metropolitan area. This procedure allows us to identify 293 metropolitan areas in both 2000 and 2007. ${ }^{11}$ However, it is important to keep in mind that parts of metropolitan areas are often

\footnotetext{
${ }^{9}$ One potentially important limitation is that high skilled workers may sort into high wage or high quality of life areas, which would bias the estimates. We include detailed controls for observable worker characteristics but some worker characteristics (e.g. innate ability) remain unobservable.

${ }^{10}$ Gabriel and Rosenthal (2004) and Chen and Rosenthal (2008) follow a related approach by computing quality of life estimates in levels (as opposed to logs) by subtracting the local wage premium from the local housing cost premium. Measuring QOL in levels requires assumptions about household labor supply and housing consumption decisions based on sample means. Their approach does not account for non-housing prices and doing so would require some assumption about non-housing consumption presumably based on income or housing consumption. ${ }^{11}$ A few small CBSAs are not identified and are not included in this study.
} 
unobservable and our resulting quality of life estimates are subject to some degree of

measurement error.

Logarithmic differences in nominal wages across areas are computed by regressing the $\log$ of the after-tax hourly wage for worker $i$ in area $j$ on a vector of individual characteristics, $X$, and a vector of area fixed-effects, $\alpha:^{12}$

$$
\ln W_{i j}=X_{i j} \beta+\alpha_{j}+\varepsilon_{i j}
$$

The individual characteristics are included to make workers roughly equivalent across areas and include variables commonly found to affect individual wages such as a quartic specification in potential experience, dummy variables for highest level of education completed, gender, marital status, whether an individual is Black, Hispanic, Asian, or Other, head of household, part-time or irregularly employed (working less than 35 hours per week or less than 35 weeks during the previous year), citizenship status, industry, and occupation. We would also like to control for other worker characteristics such as firm size and union coverage/membership, but these are not asked in the ACS and decennial census. The results for the individual characteristics are generally as expected and are available by request. The sample is restricted to workers between the ages of 25 and 61. We use wages net of federal income taxes because the progressive nature of the federal income tax system means that workers in high wage areas pay a higher percentage of their income in federal income taxes than workers in low wages areas (Henderson 1982; Albouy 2008, 2009). However, individual workers receive the same federal benefits regardless

\footnotetext{
${ }^{12}$ Pre-tax hourly wages $\left(w_{i j}\right)$ are estimated by dividing annual wage income by the number of weeks worked times the usual hours worked per week. Federal income taxes are estimated using the federal tax schedule and based on several assumptions. We assume that all married couples file jointly and receive two personal exemptions and nonmarried persons have a filing status of single and receive one personal exemption. Itemized deductions are assumed to equal 20 percent of annual income, but taxpayers take the standard deduction if it is more than their itemized deductions. Deductions and exemptions are subtracted from annual earnings to estimate taxable income. Tax schedules are then used to compute federal tax liabilities. We next compute the average tax rate for each taxpayer $\left(\tau_{i j}\right)$, and then multiply the pre-tax hourly wage by one minus the average tax rate to compute after-tax hourly wages $\left(W_{i j}=w_{i j}\left(1-\tau_{i j}\right)\right)$.
} 
of how much federal taxes they pay. Therefore, workers are ultimately concerned with wages net of federal taxes when making location decisions, and this is what we use in this study. Albouy (2009) argues that federal income tax rates should be indexed to local wages and that failing to do so significantly reduces economic activity in high wage areas because the additional tax burden makes those areas less desirable to potential migrants. This reduces local employment levels and local land and housing prices and generates locational inefficiencies. Albouy (2008) argues that failing to account for geographic differences in federal taxes causes quality of life estimates to be significantly undervalued in high wage areas such as big cities. We do not make any adjustment to wages for social security contributions or state and local taxes. ${ }^{13}$ The estimated area fixed-effects in (5) represent logarithmic differences in wages across metropolitan areas.

Logarithmic differences in rents and housing values are also based on microdata from the ACS and Census. More specifically, we regress the log of gross rents ${ }^{14}, R$, for each housing unit on a vector of housing characteristics, $F$, and a vector of area fixed-effects, $\pi$ :

$$
\ln R_{i j}=F_{i j} \Gamma+\pi_{j}+u_{i j}
$$

We also estimate a similar equation for homeowner housing values:

$$
\ln V_{i j}=F_{i j} \phi+\lambda_{j}+\xi_{i j}
$$

The housing characteristics included are dummy variables for the number of bedrooms, the total number of rooms, the age of the structure, the number of units in the building, modern plumbing,

\footnotetext{
${ }^{13}$ Social security contributions could be easily estimated but estimating Social Security benefits is much more difficult. Adjusting wages for state and local income taxes would also require accounting for other taxes and the benefits from public spending that these taxes make possible.

${ }^{14}$ Rents are measured to include certain utilities but exclude a portion of rents attributable to property tax payments based on the effective tax rates of owner-occupied housing. Removing property taxes from rents is based on the assumption that higher property taxes are offset by lowering other state and local taxes (e.g. income, sales, etc.). If this assumption holds, then including property taxes in rents to construct quality of life estimates would cause areas that heavily rely on property taxes to have higher QOL values than they should. As a practical matter, excluding property taxes has only a small effect on QOL estimates for most areas.
} 
modern kitchen facilities, and lot size (available only for single-unit buildings). These results are available upon request. The area fixed-effects from (6) and (7) are used to measure logarithmic differences in rents and housing values across metropolitan areas.

To compute quality of life estimates, we also need to account for non-housing prices. This paper estimates non-housing prices using the ACCRA Cost of Living Index. ACCRA works with local chambers of commerce to collect local prices quarterly for 57 goods and services intended to form a representative basket of typical consumer expenditures. Individual prices are then aggregated for each area to create a composite price index and six sub-indices including groceries, transportation, healthcare, miscellaneous goods and services, housing and utilities. As discussed by Koo, Phillips and Sigalla (2000) and others, there are a number of problems with using the ACCRA data to estimate cost of living differences across areas. In particular, DuMond, Hirsch and Macpherson (1999) argue that the ACCRA Composite Index is significantly over-dispersed across areas. Winters (2009) suggests that this is primarily because of ACCRA's heavy reliance on housing values for the housing index, but there are other issues as well. That said, ACCRA is the single best source of data on interarea differences in nonhousing prices available and is used in this study.

We combine non-housing prices from ACCRA with the housing price fixed-effects from (6) and (7) to construct two cost of living measures. The rent-based index is a weighted average of rents and non-housing prices excluding utilities with rents given a weight of 0.29 and nonhousing prices given a weight of 0.71 . Non-housing prices are computed as a weighted average of the ACCRA sub-indices for groceries, transportation, healthcare, and miscellaneous goods and services. Weights are chosen based on calculations from the 2005 Consumer Expenditure Survey suggesting that housing including certain utilities represents 29 percent of average 
consumption expenditures. ${ }^{15}$ The value-based index is computed as a weighted average of housing values and non-housing prices including utilities. Because utilities are now included in non-housing prices, housing values are given a weight of 0.23 and non-housing prices are given a weight of 0.77 based on CES expenditure shares.

Note that this paper assumes constant expenditure shares for housing and non-housing goods, which is consistent with Cobb-Douglas utility and an elasticity of substitution equal to one. ${ }^{16}$ Some readers might find this assumption overly restrictive, but Davis and Ortalo-Magné (2011) examine the 1980, 1990, and 2000 decennial census data and find that the expenditure share for housing is fairly constant over time and argue that Cobb-Douglas utility cannot be rejected. Though there is no consensus on the "true" elasticity of substitution between housing and non-housing, a few other studies have found similar results. Ogaki and Reinhart (1998) find an elasticity of 1.17 that is not statistically different from one at the 5\% significance level and Piazessi, Schneider, and Tuzel (2007) report estimates of 0.77 and 1.24 for two different time periods, neither of which is statistically different from one.

Another issue with the ACCRA data is that they are not available for all areas. For metropolitan areas with no ACCRA data on non-housing prices, the rent-based and value-based price indices are imputed based on information from those that are available. ${ }^{17}$ For the rentbased index, we regress $\ln \boldsymbol{P}$ on the area fixed-effects from (6) along with Census division

\footnotetext{
${ }^{15}$ Note that this expenditure share for housing differs from official reports of the CES expenditure share for both "Housing" and "Shelter." The housing share based on gross rents used herein includes certain utilities but excludes others and also excludes expenditures for household operations, housekeeping, and household furnishings. The housing share of 0.29 also differs from the official CES tabulations in that homeowner housing expenditures are measured by implicit rents and not by out-of-pocket expenses such as mortgage interest.

${ }^{16}$ An elasticity of substitution less than (greater than) one would imply a higher (lower) expenditure share for housing in areas with relatively high housing prices.

${ }^{17}$ A related problem is that prices are measured at the sub-metropolitan level, but data are not generally available for all areas within a metropolitan area. If sub-metropolitan areas for which prices are reported are not representative of places in the same metro for which prices are not reported, the average price level for the metro area will be measured with error.
} 
dummies and metropolitan area population dummies. The coefficients from this regression are then used to predict values of the rent-based index for areas with missing non-housing prices. Missing values for the value-based index are imputed similarly except that they are based on the area fixed-effects from (7).

Once we have constructed rent-based and value-based price indices for every metro area, we then subtract the logarithmic differences in wages from the logarithmic differences in prices to construct the alternative rent-based and housing value-based quality of life estimates. The next section presents these results.

\section{Quality of Life Estimates}

This section presents the results of the quality of life (QOL) estimates and discusses the differences that result from separately measuring housing prices by rents and by values. This paper differs from most previous quality of life studies because of its emphasis on measuring housing prices solely by rents instead of using a combination of rents and housing values. Summary statistics for the rent-based and housing value-based QOL estimates for 2007 are presented in Table 1. Both measures have means close to zero by construction, but the valuebased estimates are considerably more dispersed. The standard deviation for the rent-based estimates is 0.058, while the standard deviation for the value-based estimates is 0.093 . Similarly, the value-based estimates have a much wider spread between the maximum and minimum values than the rent-based estimates. The spreads between the $90^{\text {th }}$ and $10^{\text {th }}$ percentiles and the $75^{\text {th }}$ and $25^{\text {th }}$ percentiles are considerably smaller than the max-min spread, but for both the value-based QOL estimates continue to be considerably more dispersed than the rent-based estimates. 
The 2007 quality of life estimates for the top 20 cities according to the 2007 the rentbased series are presented in Table 2, and estimates for the additional cities are reported in Appendix Table A. Using the rent-based index Honolulu, $\mathrm{HI}$ is considered to have the highest quality of life with an estimate of 0.266 . The estimate suggests that workers in Honolulu accept roughly 27 percent lower real wages than what they would get from relocating to an average QOL area. Well behind Honolulu is Medford, OR in second with a rent-based QOL estimate of 0.162. Santa Barbara-Santa Maria-Goleta, CA and Burlington-South Burlington, VT are third and fourth with estimates of 0.156 and 0.154 , respectively. It would be tedious to discuss the ranking for every area, but a few general observations are useful. Metropolitan areas in California and Florida tend to do fairly well probably because of their mild winters and proximity to the coast. A few small to mid-size college towns, such as State College, PA and Morgantown, WV, also rank pretty highly. ${ }^{18}$ Winters (2011a) examines the effects of a large number of amenities on metropolitan area quality of life and finds that among other things a nice climate, a mountainous topography, a highly educated population and a strong presence of higher education institutions have significantly positive effects on quality of life. ${ }^{19}$ The bottom of the rankings is more mixed but there is some tendency toward interior areas of the country such as in parts of Indiana, Ohio and Texas. Of particular note are a few big cities that rank quite poorly such as Houston-Baytown-Huntsville, TX at $289^{\text {th }}$ and Detroit-Warren-Flint, MI at $290^{\text {th }}$ out of 293.

\footnotetext{
${ }^{18}$ State College is home to Pennsylvania State University and Morgantown is the home of the University of West Virginia. Winters (2011b) also shows that college towns are growing faster than other metropolitan areas and suggests that it is because recent student in-migrants often develop friendships, relationships with local employers, and a taste for local amenities and decide to stay in the area after their education is complete.

${ }^{19}$ Winters (2011) also finds mixed results for some other common (dis)amenities such as crime, pollution, commute times, population density, and city size.
} 
Though there are some differences, the rankings using the value-based estimates are largely similar. In fact, the Spearman rank correlation between the two series is very high at $0.746 .^{20}$ The important difference, though, is that the value-based estimates are considerably more dispersed, especially at the very top of the rankings. Honolulu is still the top ranked area according to the value-based series, but its QOL estimate increases to 0.402. Santa BarbaraSanta Maria-Goleta and Medford swap the second and third positions with estimates of 0.323 and 0.311 , respectively. Though there are some exceptions, the value-based estimates for the nicest areas are generally larger than the rent-based estimates. Rents are an appropriate measure of the present user cost of housing, but housing values are not and should not be used as a proxy for rents. Housing values in 2007 are considerably more dispersed across areas than rents, and quality of life estimates based on values are considerably more dispersed than QOL estimates based on rents.

While using housing values to compute QOL estimates is certainly a problem for 2007 , one might think that it would not be much of a problem for more "normal" times. After all 2007 was the peak of the housing bubble and values were definitely inflated, especially in areas with an inelastic supply of housing (Glaeser, Gyourko and Saiz 2008). To investigate the extent of problems from using housing values to measure QOL in more normal times, we next compute rent-based and value-based QOL estimates for 2000. Table 3 reports the summary statistics for 2000. Means are still small and roughly equal for the two series, and the value-based estimates are again more dispersed than the rent-based estimates, though by considerably less than in 2000 . The standard deviation is 0.071 for the rent-based estimates and 0.080 for the value-based estimates. The max-min, 90-10, and 75-25 spreads are also larger for the value-based estimates than the rent-based estimates. Note also that the rent-based QOL estimates became generally

\footnotetext{
${ }^{20}$ The correlation for the estimates themselves is also very high at 0.752 .
} 
less dispersed between 2000 and 2007, while the value-based estimates became more dispersed over the same period.

Table 4 reports the QOL estimates for the top 20 areas in 2000 according to the rentbased series; results for the additional areas are available from the author by request. Again the value-based estimates are more dispersed, but there is a very high Spearman rank correlation between the two series of 0.883 . According to the rent-based estimates, Prescott, AZ and Missoula, MT occupied the top two positions in 2000 with QOL estimates of 0.195 and 0.194 . Prescott is a small metro area in the mountains of central Arizona with fairly mild winters and warm summers. Missoula is also a small metropolitan area with low population density and nice outdoor recreation amenities and is home to the University of Montana (Howie, Murphy, and Wicks 2010). The next three spots and several others in the top 20 are also small areas in the Mountain Census Division.

There are some differences in the QOL rankings between 2000 and 2007, but the rankings are quite highly correlated across the two years. The rent-based estimates in 2000 and 2007 have a Spearman rank correlation of 0.740, and the value-based estimates in 2000 and 2007 have a Spearman rank correlation of 0.731 . We have also examined changes in QOL between 2000 and 2007. The biggest gainers and losers tend to be smaller metro areas. In particular, several of the smaller metros in the Mountain Census Division saw sizable decreases in quality of life estimates between 2000 and 2007 including Prescott, AZ, Billings, MT and Cheyenne WY. Further inspection (not shown) reveals that the decrease in quality of life estimates for these small metros in the Mountain states was driven largely by an apparent positive productivity shock that increased wages. The relatively short time period and the slow migration of labor to relatively remote areas may cause quality of life to be undervalued in 2007 for these areas. Time 
will tell if these small mountain areas return to the top of the rankings in future years or if their values in 2000 were actually aberrations from their long run values. An alternative explanation is that the relatively small samples for small metros might lead to sizable measurement error and imprecise estimates. Either way, the differences across years for small metro areas suggest that we should be careful in placing too much confidence in quality of life estimates for small areas in a given year.

Many large dense metro areas saw improved rankings between 2000 and 2007 including Boston (227 to 113), Los Angeles (129 to 52), Miami (123 to 37), New York (173 to 120), Philadelphia (275 to 161), San Jose-San Francisco ( 86 to 40), and Washington-Baltimore (228 to 187). Honolulu has a population of nearly one million people and saw its quality of life rank increase from number 31 in 2000 to number 1 in 2007. Closer inspection reveals that the QOL increase for many of these cities was driven by increases in housing costs. There were also some notable deteriorations in relative quality of life among fairly large cities including Denver (140 to 182), Phoenix (131 to 208), and Pittsburgh (154 to 222).

One might also be interested in how the quality of life rankings in this paper compare to others in recent studies. Table 5 reports the rent-based and value-based quality of life rankings for the 20 largest metros in 2000 and compares these to the rankings in Chen and Rosenthal (2008) and Albouy (2008). ${ }^{21}$ There is no single recent study considered a benchmark, but both Chen and Rosenthal (2008) and Albouy (2008) have received considerable attention recently. Both Chen and Rosenthal (2008) and Albouy (2008) use a combination of rents and housing values to measure housing prices. There are a number of other important differences in how these rankings are constructed including the number of areas that are ranked, so differences are to be expected, e.g., New York is ranked highly by the value-based index and by Albouy (2008)

${ }^{21}$ We are not aware of any other rankings for 2007, so we only compare rankings for 2000. 
but ranked poorly by the rent-based index and by Chen and Rosenthal (2008). However, there are also some similarities; San Diego does well across all the rankings and Houston ranks poorly. Not surprisingly, the value-based index tends to be closer to the Chen and Rosenthal (2008) and Albouy (2008) than the rent-based index.

\section{Effects of Quality of Life on Changes in Rents and Values}

This section examines the relationship between quality of life in 2000 and the changes in rental prices and home values between 2000 and 2007. That home values increased during this period both absolutely and relative to rents has been widely documented. The first two columns of Table 6 regress the changes in log rent and log value fixed effects on the rent-based quality of life index for 2000. The results show that both rents and values increased disproportionately in high quality of life areas with statistically significant coefficients of 0.155 and 0.867 . The magnitudes are much larger for values than rents. Based on the summary statistics reported in Table 3, moving from the $10^{\text {th }}$ percentile to the $90^{\text {th }}$ percentile of rent-based quality of life (an increase of 0.188 ) is associated with a 0.163 increase in log home values but only a 0.029 increase in log rents. These results suggest that the demand for housing in high quality of life areas increased considerably between 2000 and 2007. However, the much greater increase in values than rents suggests that market participants expected the demand for living in high quality of life areas to continue to grow.

A complementary approach is to look at housing value-rent ratios (aka price-rent ratio or inversely rent-price ratio) and examine how these relate to quality of life across areas. A higher value-rent ratio indicates that the demand for housing in the area is expected to grow faster than other areas (Campbell et al. 2009). Higher future demand for local housing does not affect 
current rental payments because these reflect the present user cost of housing, but higher future demand does increase current housing values. The third and fourth columns of Table 6 regress the log value-rent ratios in 2000 and 2007 on the rent-based quality of life estimate for 2000. The results in both columns suggest that a higher quality of life increases the value-rent ratio in an area with coefficients of 0.432 and 1.144 in 2000 and 2007, respectively. ${ }^{22}$ These results suggest that the demand for housing was expected to increase in high quality of life areas in both years, but by 2007 the expected growth in demand had grown quite considerably as values grew much more quickly than rents. As economists and the general public were soon reminded, however, expectations are not always accurate and asset values based on them can often become considerably distorted. Hence, quality of life rankings should use housing rents and not housing values.

\section{Conclusion}

This paper presents quality of estimates for 293 metropolitan areas in the year 2007 based on differences in real wages across areas, where real wages are defined as nominal wages adjusted for the local cost of living. Households receive utility from the quality of life in an area and are willing to accept lower real wages to live in areas with nice amenities. The spatial equilibrium hypothesis says that utility for identical workers should be equal across locations, and a variant of the Rosen-Roback model shows that quality of life differences across areas can be measured by differences in real wages. An important issue, though, is whether housing prices should be measured by rental payments, owner-occupied housing values, or some combination of the two. On theoretical grounds, rents are the superior measure of housing prices because rents

\footnotetext{
${ }^{22}$ Lee and You (2011) also document that the value-income ratio is higher in high quality of life areas but they do not focus on changes over time.
} 
reflect the current user cost of housing, but housing values are based on the net present value of future rental income and do not necessarily reflect the present user cost of housing. However, many researchers have used a combination of rents and values assuming that the two basically measure the same thing.

We compute separate quality of life estimates that measure housing prices by rents and by values. The two series are highly correlated, but the housing value-based estimates are considerably more dispersed. This is likely due in large part to the recent housing bubble, but examination of quality of life estimates using data from 2000 shows a similar result, though to a lesser extent. Expected and actual growth in rental payments differs across areas causing housing values to be more dispersed than rents across areas. We conclude that future researchers should be cautious in using housing values to measure housing prices in estimating quality of life differences across areas. 


\section{References}

Albouy D (2008) Are big cities really bad places to live? Improving quality-of-life estimates across cities. NBER WP 14472

Albouy D (2009) The unequal geographic burden of federal taxation. J Polit Econ 117(4):635667

Banzhaf HS, Farooque O (2012) Interjurisdictional housing prices and spatial amenities: which measures of housing prices reflect local public goods? NBER WP 17809

Beeson PE, Eberts, RW (1989) Identifying productivity and amenity effects in interurban wage differentials. Rev Econ Stat 71(3):443-452

Blomquist GC, Berger MC, Hoehn, JP (1988) New estimates of quality of life in urban areas. Amer Econ Rev 78(1):89-107

Campbell SD, Davis MA, Gallin J, Martin RF (2011) What moves housing markets: a variance decomposition of the rent-price ratio. J Urban Econ 66(2):90-102

Chen Y, Rosenthal SS (2008) Local amenities and life-cycle migration: Do people move for jobs or fun? J Urban Econ, 64(3):519-537

Clark TE (1995) Rents and prices of housing across areas of the United States: a cross-section examination of the present value model. Reg Sci Urban Econ 25(2):237-247

Davis MA, Lehnert A, Martin RF (2008) The rent-price ratio for the aggregate stock of owneroccupied housing. Rev Income Wealth 54(2):279-284

Davis MA, Ortalo-Magné F (2011) Household expenditures, wages, rents. Rev Econ Dyn14(2):248-261

DuMond JM, Hirsch BT, Macpherson DA (1999) Wage differentials across labor markets and workers: does cost of living matter? Econ Inq 37(4):577-598 
Gabriel SA, Mattey JP, Wascher WL (2003) Compensating differentials and evolution in the quality of life among U.S. states. Reg Sci Urban Econ 33(5):619-649

Gabriel SA, Rosenthal SS (2004) Quality of the business environment versus quality of life: do firms and households like the same cities? Rev Econ Stat 86(1):438-444

Garner TI, Verbrugge R (2009) Reconciling user costs and rental equivalence: evidence from the US consumer expenditure survey. J Hous Econ 18(3):172-192

Glaeser EL, Gyourko J, Saiz A (2008) Housing supply and housing bubbles. J Urban Econ 64(2):198-217

Greenwood MJ, Hunt G, Rickman DS, Treyz GI (2001) Migration, regional equilibrium, and the estimation of compensating differentials. Amer Econ Rev 81(5):1382-1390

Gyourko J, Kahn M, Tracy J (1999) Quality of life and environmental comparisons. In: Cheshire P, Mills ES (eds) Handbook of regional and urban economics, vol. 3. North Holland, Amsterdam, pp 1413-1454

Gyourko J, Tracy J (1991) The structure of local public finance and the quality of life. J Polit Econ 99(4):774-806

Henderson JV (1982) Evaluating consumer amenities and interregional welfare differences. J Urban Econ 11(1):32-59

Howie P, Murphy SM, Wicks J (2010) An application of a stated preference method to value urban amenities. Urban Stud 47(2):235-256

Kahn ME (1995) A revealed preference approach to ranking city quality of life. J Urban Econ 38(2):221-235

Koo J, Phillips KR, Sigalla FD (2000) Measuring regional cost of living. J Bus Econ Stat 18(1):127-136 
Krupka DJ, Donaldson K (2007) Wages, rents and heterogeneous moving costs. IZA DP 3224

Lee S, You SD (2011) The price-to-income ratio and the quality of life. University of British Columbia Working Paper

Ogaki M, Reinhart CM (1998) Measuring intertemporal substitution: the role of durable goods. J Polit Econ 106(5):1078-1098

Oswald AJ, Wu S (2010) Objective confirmation of subjective measures of human well-being: evidence from the USA. Sci 327 (2010):576-579

Oswald AJ, Wu S (2011) Well-being across America. Rev Econ Stat 93(4):1118-1134

Partridge MD, Rickman DS, Olfert MR, Ali K (2012) Dwindling U.S. internal migration: evidence of spatial equilibrium or structural shifts in local labor markets? Reg Sci Urban Econ 42(1-2):375-388

Piazessi M, Schneider M, Tuzel S (2007) Housing, consumption, and asset pricing. J Financ Econ 83(3):531-569

Rappaport J (2007) Moving to nice weather. Reg Sci Urban Econ 37(3):375-398

Rappaport J (2009) The increasing importance of quality of life. J Econ Geogr 9(6):779-804

Roback J (1982) Wages, rents, and the quality of life. J Polit Econ 90(6):1257-1278

Rosen S (1979) Wage-based indexes of urban quality of life. In: Mieskowski P, Straszheim M (eds) Current issues in urban economics. Johns Hopkins University Press, Baltimore, pp 74-104

Ruggles S, Sobek M, Alexander T, Fitch CA, Goeken R, Hall PK, King M, Ronnander C (2008) Integrated Public Use Microdata Series: Version 4.0. Minneapolis: Minnesota Population Center 
Shapiro JM (2006) Smart cities: quality of life, productivity, and the growth effects of human capital. Rev Econ Stat 88(2):324-335

Stover ME, Leven CL (1992) Methodological issues in the determination of the quality of life in urban areas. Urban Stud 29(5):737-754

Verbrugge R (2008) The puzzling divergence of aggregate rents and user costs, 1980-2004. Rev Income Wealth 54(4):671-699

Winters JV (2009) Wages and Prices: are workers fully compensated for cost of living differences? Reg Sci Urban Econ 39(5):632-643

Winters JV (2011a) Human capital, higher education institutions, and quality of life. Reg Sci Urban Econ 41(5):446-454

Winters JV (2011b) Why are smart cities growing? Who moves and who stays. J Reg Sci 51(2):253-270 
Table 1: Summary Statistics for QOL Estimates, 2007

\begin{tabular}{lcc} 
& Rent-based QOL Estimate & Value-based QOL Estimate \\
\hline Mean & 0.005 & 0.001 \\
Standard Deviation & 0.058 & 0.093 \\
Max - Min & 0.435 & 0.604 \\
90th - 10th percentile & 0.143 & 0.225 \\
75th - 25th percentile & 0.080 & 0.105 \\
\hline
\end{tabular}

$\mathrm{N}=293$. 
Table 2: Quality of Life Estimates and Rankings, 2007

\begin{tabular}{lcccc}
\hline CBSA/CSA Name & $\begin{array}{c}\text { Rent-based } \\
\text { QOL Est. }\end{array}$ & $\begin{array}{c}\text { Rent-based } \\
\text { QOL Rank }\end{array}$ & $\begin{array}{c}\text { Value-based } \\
\text { QOL Est. }\end{array}$ & $\begin{array}{c}\text { Value-based } \\
\text { QOL Rank }\end{array}$ \\
\hline Honolulu, HI CBSA & 0.266 & 1 & 0.402 & 1 \\
Medford, OR CBSA* & 0.162 & 2 & 0.311 & 3 \\
Santa Barbara-Santa Maria-Goleta, CA CBSA* & 0.156 & 3 & 0.323 & 2 \\
Burlington-South Burlington, VT CBSA & 0.154 & 4 & 0.173 & 15 \\
State College, PA CBSA* & 0.143 & 5 & 0.126 & 31 \\
Fort Walton Beach-Crestview-Destin, FL CBSA* & 0.129 & 6 & 0.116 & 33 \\
Chico, CA CBSA* & 0.124 & 7 & 0.248 & 7 \\
Morgantown, WV CBSA & 0.111 & 8 & 0.066 & 62 \\
Bangor, ME CBSA & 0.110 & 9 & 0.098 & 38 \\
Eugene-Springfield, OR CBSA & 0.108 & 10 & 0.164 & 18 \\
San Luis Obispo-Paso Robles, CA CBSA* & 0.106 & 11 & 0.303 & 4 \\
Blacksburg-Christiansburg-Radford, VA CBSA* & 0.104 & 12 & 0.059 & 65 \\
Coeur d'Alene, ID CBSA* & 0.102 & 13 & 0.209 & 11 \\
Anchorage, AK CBSA & 0.098 & 14 & 0.093 & 45 \\
St. George, UT CBSA & 0.094 & 15 & 0.094 & 43 \\
Bowling Green, KY CBSA & 0.092 & 16 & 0.024 & 94 \\
Panama City-Lynn Haven, FL CBSA* & 0.091 & 17 & 0.088 & 48 \\
Missoula, MT CBSA & 0.089 & 18 & 0.154 & 20 \\
New Orleans-Metairie-Bogalusa, LA CSA & 0.089 & 19 & -0.020 & 155 \\
Portland-Vancouver-Beaverton, OR-WA CBSA & 0.088 & 20 & 0.157 & 19 \\
\hline
\end{tabular}

*Indicates non-housing prices are imputed for the CBSA/CSA. 
Table 3: Summary Statistics for QOL Estimates, 2000

\begin{tabular}{lcc} 
& Rent-based QOL Estimate & Value-based QOL Estimate \\
\hline Mean & -0.027 & -0.029 \\
Standard Deviation & 0.071 & 0.080 \\
Max - Min & 0.429 & 0.485 \\
90th - 10th percentile & 0.188 & 0.208 \\
75th - 25th percentile & 0.093 & 0.098 \\
\hline
\end{tabular}

$\mathrm{N}=293$. 
Table 4: Quality of Life Estimates and Rankings, 2000

\begin{tabular}{lcccc}
\hline CBSA/CSA Name & \multicolumn{3}{c}{ Rent-based } & Rent-based \\
& QOL Est. & QOL Rank & QOL Est. & QOL Rank \\
\hline Prescott, AZ CBSA & 0.196 & 1 & 0.246 & 1 \\
Missoula, MT CBSA & 0.195 & 2 & 0.217 & 2 \\
St. George, UT CBSA & 0.157 & 3 & 0.159 & 7 \\
Billings, MT CBSA* & 0.131 & 4 & 0.140 & 13 \\
Cheyenne, WY CBSA & 0.127 & 5 & 0.105 & 23 \\
Fort Walton Beach-Crestview-Destin, FL CBSA* & 0.116 & 6 & 0.068 & 33 \\
Flagstaff, AZ CBSA & 0.105 & 7 & 0.098 & 27 \\
Eugene-Springfield, OR CBSA & 0.103 & 8 & 0.145 & 10 \\
Great Falls, MT CBSA* & 0.102 & 9 & 0.141 & 12 \\
Coeur d'Alene, ID CBSA* & 0.100 & 10 & 0.136 & 14 \\
Grand Junction, CO CBSA & 0.099 & 11 & 0.121 & 17 \\
Morgantown, WV CBSA & 0.089 & 12 & 0.009 & 82 \\
Albany-Corvallis-Lebanon, OR CSA* & 0.089 & 13 & 0.129 & 15 \\
Panama City-Lynn Haven, FL CBSA* & 0.089 & 14 & 0.061 & 36 \\
Lake Havasu City-Kingman, AZ CBSA & 0.086 & 15 & 0.102 & 24 \\
Medford, OR CBSA* & 0.084 & 16 & 0.153 & 9 \\
Casper, WY CBSA* & 0.084 & 17 & 0.101 & 25 \\
Chico, CA CBSA* & 0.083 & 18 & 0.116 & 19 \\
Abilene, TX CBSA & 0.082 & 19 & 0.025 & 67 \\
Lewiston, ID-WA CBSA* & 0.080 & 20 & 0.106 & 22 \\
\hline
\end{tabular}

* Indicates that non-housing prices are imputed for the CBSA/CSA. 
Table 5: Comparison of Year 2000 QOL Ranks for 20 Largest Metro Areas

\begin{tabular}{lcccc}
\hline CBSA/CSA Name & $\begin{array}{c}\text { Rent-based } \\
\text { QOL Rank } \\
\text { (out of 293) }\end{array}$ & $\begin{array}{c}\text { Value-based } \\
\text { QOL Rank } \\
\text { (out of 293) }\end{array}$ & $\begin{array}{c}\text { Chen-Rosenthal } \\
\text { QOL Rank } \\
\text { (out of 346) }\end{array}$ & $\begin{array}{c}\text { Albouy } \\
\text { QOL Rank } \\
\text { (out of 241) }\end{array}$ \\
\hline New York-Newark-Bridgeport, NY-NJ-CT-PA & 173 & 41 & 203 & 43 \\
Los Angeles-Long Beach-Riverside, CA & 129 & 42 & 20 & 17 \\
Chicago-Naperville-Michigan City, IL-IN-WI & 267 & 229 & 274 & 80 \\
Washington-Baltimore-N. VA, DC-MD-VA-WV & 228 & 258 & 316 & 116 \\
Boston-Worcester-Manchester, MA-RI-NH & 227 & 81 & 91 & 34 \\
San Jose-San Francisco-Oakland, CA & 86 & 6 & 3 & 6 \\
Philadelphia-Camden-Vineland, PA-NJ-DE-MD & 275 & 275 & 340 & 184 \\
Dallas-Fort Worth, TX & 247 & 285 & 323 & 176 \\
Detroit-Warren-Flint, MI & 291 & 289 & 342 & 186 \\
Miami-Fort Lauderdale-Pompano Beach, FL & 123 & 187 & 75 & 33 \\
Houston-Baytown-Huntsville, TX & 280 & 292 & 335 & 221 \\
Atlanta-Sandy Springs-Gainesville, GA-AL & 219 & 280 & 295 & 175 \\
Seattle-Tacoma-Olympia, WA & 138 & 74 & 68 & 30 \\
Minneapolis-St. Paul-St. Cloud, MN-WI & 215 & 237 & 313 & 143 \\
Phoenix-Mesa-Scottsdale, AZ & 131 & 201 & 205 & 62 \\
Cleveland-Akron-Elyria, OH & 230 & 160 & 288 & 126 \\
San Diego-Carlsbad-San Marcos, CA & 22 & 11 & 12 & 7 \\
St. Louis-St. Charles-Farmington, MO-IL & 272 & 279 & 307 & 170 \\
Denver-Aurora-Boulder, CO & 140 & 140 & 127 & 35 \\
Pittsburgh-New Castle, PA & 154 & 109 & 287 & 188 \\
\hline
\end{tabular}


Table 6: Effects of Rent-based QOL on Changes in Log Rents and Home Values, 2000-2007 Dependent $\Delta$ Ln Rent FE, $\Delta$ Ln Value FE, Ln Value-Rent Ln Value-Rent Variable 2000-2007

Rent-based QOL $0.155^{* * *}$ 2000-2007 Ratio, 2000 Ratio, 2007

\begin{tabular}{l}
$\mathrm{R}^{2}$ \\
\hline
\end{tabular}

(0.056) $0.867 * * *$ $0.432 * * *$ $1.144 * * *$

$(0.143)$

$(0.132)$

$(0.217)$

Standard errors in parentheses. ***Significant at $1 \%$. 
Appendix Table A: Complete Quality of Life Estimates and Rankings, 2000 \& 2007

\begin{tabular}{|c|c|c|c|c|c|c|c|c|}
\hline CBSA/CSA Name & $\begin{array}{c}\text { Rent- } \\
\text { based } \\
\text { Est. } \\
2007 \\
\end{array}$ & $\begin{array}{l}\text { Rent- } \\
\text { based } \\
\text { Rank } \\
2007 \\
\end{array}$ & $\begin{array}{c}\text { Value- } \\
\text { based } \\
\text { Est. } \\
2007 \\
\end{array}$ & $\begin{array}{l}\text { Value- } \\
\text { based } \\
\text { Rank } \\
2007\end{array}$ & $\begin{array}{c}\text { Rent- } \\
\text { based } \\
\text { Est. } \\
2000 \\
\end{array}$ & $\begin{array}{l}\text { Rent- } \\
\text { based } \\
\text { Rank } \\
2000 \\
\end{array}$ & $\begin{array}{c}\text { Value- } \\
\text { based } \\
\text { Est. } \\
2000\end{array}$ & $\begin{array}{c}\text { Value- } \\
\text { based } \\
\text { Rank } \\
2000 \\
\end{array}$ \\
\hline Abilene, TX CBSA & 0.058 & 48 & -0.054 & 209 & 0.082 & 19 & 0.025 & 67 \\
\hline Albany, GA CBSA & -0.013 & 175 & -0.046 & 200 & -0.104 & 255 & -0.115 & 261 \\
\hline Albany-Corvallis-Lebanon, OR CSA* & 0.058 & 50 & 0.146 & 21 & 0.089 & 13 & 0.129 & 15 \\
\hline Albany-Schenectady-Amsterdam, NY CSA & -0.034 & 216 & -0.033 & 174 & -0.120 & 265 & -0.097 & 242 \\
\hline Albuquerque, NM CBSA & 0.007 & 136 & -0.009 & 140 & 0.011 & 91 & 0.009 & 83 \\
\hline Alexandria, LA CBSA* & 0.056 & 53 & -0.032 & 172 & 0.015 & 83 & -0.013 & 110 \\
\hline Allentown-Bethlehem-Easton, PA-NJ CBSA* & -0.015 & 178 & 0.023 & 96 & -0.111 & 259 & -0.077 & 213 \\
\hline Altoona, PA CBSA* & 0.041 & 78 & -0.005 & 133 & -0.071 & 211 & -0.056 & 181 \\
\hline Amarillo, TX CBSA & -0.003 & 160 & -0.067 & 226 & -0.011 & 117 & -0.048 & 167 \\
\hline Ames-Boone, IA CSA & 0.028 & 100 & 0.014 & 104 & -0.020 & 132 & -0.036 & 139 \\
\hline Anchorage, AK CBSA & 0.098 & 14 & 0.093 & 45 & -0.001 & 105 & -0.043 & 158 \\
\hline Anniston-Oxford, AL CBSA & 0.051 & 58 & -0.009 & 138 & 0.002 & 98 & -0.016 & 115 \\
\hline Appleton-Oshkosh-Neenah, WI CSA* & -0.099 & 286 & -0.060 & 219 & -0.132 & 273 & -0.096 & 241 \\
\hline Asheville-Brevard, NC CSA & 0.049 & 63 & 0.075 & 57 & 0.058 & 42 & 0.085 & 31 \\
\hline Athens-Clarke County, GA CBSA* & 0.034 & 88 & 0.012 & 107 & -0.010 & 116 & -0.021 & 120 \\
\hline Atlanta-Sandy Springs-Gainesville, GA-AL CSA & -0.026 & 206 & -0.101 & 267 & -0.074 & 219 & -0.148 & 280 \\
\hline Atlantic City-Hammonton, NJ CBSA* & -0.053 & 250 & 0.031 & 81 & -0.232 & 293 & -0.197 & 290 \\
\hline Augusta-Richmond County, GA-SC CBSA & -0.048 & 241 & -0.086 & 251 & -0.062 & 194 & -0.072 & 206 \\
\hline Austin-Round Rock, TX CBSA & -0.016 & 185 & -0.066 & 224 & -0.028 & 145 & -0.089 & 231 \\
\hline Bakersfield, CA CBSA & -0.023 & 201 & 0.044 & 73 & -0.063 & 200 & -0.055 & 179 \\
\hline Bangor, ME CBSA & 0.110 & 9 & 0.098 & 38 & 0.055 & 43 & 0.059 & 38 \\
\hline Barnstable Town, MA CBSA* & 0.038 & 81 & 0.185 & 13 & -0.005 & 111 & 0.113 & 20 \\
\hline Baton Rouge-Pierre Part, LA CSA & -0.011 & 172 & -0.080 & 243 & -0.051 & 179 & -0.074 & 208 \\
\hline Battle Creek, MI CBSA* & 0.004 & 146 & -0.040 & 188 & -0.116 & 261 & -0.140 & 274 \\
\hline Beaumont-Port Arthur, TX CBSA & -0.097 & 284 & -0.186 & 292 & -0.133 & 274 & -0.183 & 288 \\
\hline Bellingham, WA CBSA & 0.028 & 104 & 0.142 & 22 & 0.070 & 30 & 0.107 & 21 \\
\hline Bend-Prineville, OR CSA* & 0.059 & 46 & 0.243 & 8 & 0.061 & 35 & 0.121 & 18 \\
\hline Billings, MT CBSA* & 0.031 & 94 & 0.020 & 99 & 0.131 & 4 & 0.140 & 13 \\
\hline Binghamton, NY CBSA* & -0.016 & 184 & -0.055 & 212 & -0.040 & 161 & -0.029 & 131 \\
\hline Birmingham-Hoover-Cullman, AL CSA & -0.017 & 188 & -0.080 & 244 & -0.089 & 242 & -0.118 & 263 \\
\hline Bismarck, ND CBSA* & 0.009 & 131 & -0.043 & 196 & 0.061 & 36 & 0.045 & 45 \\
\hline Blacksburg-Christiansburg-Radford, VA CBSA* & 0.104 & 12 & 0.059 & 65 & 0.017 & 76 & -0.005 & 96 \\
\hline Bloomington, IN CBSA & 0.051 & 57 & -0.021 & 156 & 0.028 & 65 & -0.003 & 95 \\
\hline Bloomington-Normal, IL CBSA & -0.043 & 232 & -0.078 & 241 & -0.099 & 249 & -0.103 & 249 \\
\hline Boise City-Nampa, ID CBSA* & 0.022 & 115 & 0.043 & 74 & 0.000 & 101 & -0.027 & 127 \\
\hline Boston-Worcester-Manchester, MA-RI-NH CSA & 0.022 & 113 & 0.130 & 27 & -0.078 & 227 & 0.011 & 81 \\
\hline Bowling Green, KY CBSA & 0.092 & 16 & 0.024 & 94 & 0.028 & 66 & -0.007 & 103 \\
\hline Brownsville-Harlingen-Raymondville, TX CSA & -0.089 & 281 & -0.111 & 273 & -0.028 & 144 & -0.035 & 137 \\
\hline Brunswick, GA CBSA* & 0.014 & 125 & 0.047 & 72 & -0.062 & 196 & -0.050 & 171 \\
\hline Buffalo-Niagara-Cattaraugus, NY CSA & -0.061 & 257 & -0.071 & 233 & -0.118 & 264 & -0.091 & 233 \\
\hline Burlington-South Burlington, VT CBSA & 0.154 & 4 & 0.173 & 15 & 0.070 & 28 & 0.092 & 29 \\
\hline Canton-Massillon, $\mathrm{OH}$ CBSA* & -0.053 & 251 & -0.039 & 185 & -0.064 & 202 & -0.040 & 149 \\
\hline Cape Coral-Fort Myers, FL CBSA & 0.002 & 148 & 0.030 & 82 & 0.008 & 92 & 0.001 & 90 \\
\hline Casper, WY CBSA* & -0.039 & 226 & -0.045 & 197 & 0.084 & 17 & 0.101 & 25 \\
\hline Cedar Rapids, IA CBSA & -0.012 & 174 & -0.028 & 163 & -0.084 & 235 & -0.067 & 197 \\
\hline Champaign-Urbana, IL CBSA & 0.015 & 123 & -0.025 & 160 & -0.027 & 143 & -0.063 & 191 \\
\hline Charleston, WV CBSA & -0.023 & 200 & -0.067 & 229 & -0.075 & 222 & -0.081 & 223 \\
\hline Charleston-North Charleston-Summerv., SC CBSA & 0.069 & 38 & 0.041 & 75 & 0.018 & 73 & -0.008 & 105 \\
\hline
\end{tabular}




\begin{tabular}{|c|c|c|c|c|c|c|c|c|}
\hline Charlotte-Gastonia-Salisbury, NC-SC CSA & -0.048 & 238 & -0.092 & 259 & -0.062 & 197 & -0.085 & 225 \\
\hline Charlottesville, VA CBSA & 0.075 & 34 & 0.096 & 40 & 0.035 & 57 & 0.006 & 87 \\
\hline Chattanooga-Cleveland-Athens, TN-GA CSA & -0.036 & 221 & -0.047 & 202 & -0.033 & 151 & -0.039 & 147 \\
\hline Cheyenne, WY CBSA & 0.022 & 114 & 0.007 & 115 & 0.127 & 5 & 0.105 & 23 \\
\hline Chicago-Naperville-Michigan City, IL-IN-WI CSA & -0.062 & 259 & -0.038 & 182 & -0.126 & 267 & -0.086 & 229 \\
\hline Chico, CA CBSA* & 0.124 & 7 & 0.248 & 7 & 0.083 & 18 & 0.116 & 19 \\
\hline Cincinnati-Middletown-Wilm., OH-KY-IN CSA & -0.108 & 287 & -0.128 & 281 & -0.144 & 284 & -0.129 & 271 \\
\hline Clarksville, TN-KY CBSA* & 0.051 & 59 & 0.006 & 118 & 0.012 & 89 & -0.023 & 124 \\
\hline Cleveland-Akron-Elyria, OH CSA & -0.040 & 229 & -0.049 & 205 & -0.082 & 230 & -0.045 & 160 \\
\hline Coeur d'Alene, ID CBSA* & 0.102 & 13 & 0.209 & 11 & 0.100 & 10 & 0.136 & 14 \\
\hline College Station-Bryan, TX CBSA* & 0.028 & 102 & -0.028 & 162 & -0.016 & 125 & -0.081 & 221 \\
\hline Colorado Springs, CO CBSA & 0.058 & 47 & -0.005 & 134 & 0.049 & 50 & -0.020 & 119 \\
\hline Columbia, MO CBSA & 0.028 & 101 & -0.032 & 170 & 0.067 & 32 & 0.031 & 61 \\
\hline Columbia-Newberry, SC CSA & -0.032 & 214 & -0.098 & 262 & -0.071 & 209 & -0.095 & 238 \\
\hline Columbus-Auburn-Opelika, GA-AL CSA & 0.053 & 56 & -0.012 & 145 & 0.000 & 102 & -0.037 & 143 \\
\hline Columbus-Marion-Chillicothe, OH CSA & -0.063 & 261 & -0.089 & 255 & -0.126 & 266 & -0.114 & 260 \\
\hline Corpus Christi-Kingsville, TX CSA & -0.018 & 189 & -0.113 & 275 & -0.060 & 192 & -0.108 & 256 \\
\hline Cumberland, MD-WV CBSA* & -0.038 & 224 & 0.003 & 121 & -0.018 & 128 & 0.026 & 66 \\
\hline Dallas-Fort Worth, TX CSA & -0.071 & 271 & -0.148 & 287 & -0.096 & 247 & -0.166 & 285 \\
\hline Dalton, GA CBSA* & 0.011 & 129 & -0.012 & 144 & -0.016 & 124 & -0.035 & 138 \\
\hline Danville, IL CBSA & -0.068 & 266 & -0.091 & 256 & -0.050 & 177 & -0.050 & 170 \\
\hline Danville, VA CBSA* & -0.003 & 157 & -0.082 & 247 & -0.022 & 139 & -0.021 & 122 \\
\hline Davenport-Moline-Rock Island, IA-IL CBSA & -0.025 & 204 & -0.030 & 168 & -0.058 & 189 & -0.051 & 172 \\
\hline Dayton-Springfield-Greenville, OH CSA & -0.040 & 228 & -0.065 & 223 & -0.117 & 262 & -0.106 & 253 \\
\hline Decatur, IL CBSA* & -0.089 & 282 & -0.169 & 291 & -0.138 & 277 & -0.145 & 277 \\
\hline Denver-Aurora-Boulder, CO CSA & -0.015 & 182 & -0.019 & 151 & -0.022 & 140 & -0.036 & 140 \\
\hline Des Moines-Newton-Pella, IA CSA & -0.068 & 268 & -0.110 & 272 & -0.056 & 188 & -0.085 & 227 \\
\hline Detroit-Warren-Flint, MI CSA & -0.121 & 290 & -0.132 & 282 & -0.217 & 291 & -0.192 & 289 \\
\hline Dothan-Enterprise-Ozark, AL CSA & 0.045 & 70 & -0.002 & 128 & -0.009 & 114 & -0.024 & 125 \\
\hline Dover, DE CBSA & 0.008 & 135 & -0.059 & 216 & -0.022 & 137 & -0.042 & 155 \\
\hline Dubuque, IA CBSA & 0.036 & 84 & 0.029 & 83 & -0.021 & 135 & 0.003 & 89 \\
\hline Duluth, MN-WI CBSA* & 0.000 & 152 & 0.026 & 89 & -0.090 & 244 & -0.067 & 195 \\
\hline Eau Claire-Menomonie, WI CSA & 0.023 & 112 & 0.000 & 125 & -0.034 & 153 & -0.006 & 99 \\
\hline El Centro, CA CBSA* & -0.125 & 292 & 0.023 & 95 & -0.069 & 207 & -0.059 & 185 \\
\hline El Paso, TX CBSA & -0.009 & 166 & -0.017 & 148 & -0.049 & 174 & -0.060 & 186 \\
\hline Elmira, NY CBSA* & 0.044 & 74 & -0.029 & 166 & -0.037 & 156 & -0.059 & 184 \\
\hline Erie, PA CBSA & -0.039 & 227 & -0.031 & 169 & -0.075 & 223 & -0.038 & 146 \\
\hline Eugene-Springfield, OR CBSA & 0.108 & 10 & 0.164 & 18 & 0.103 & 8 & 0.145 & 10 \\
\hline Evansville, IN-KY CBSA & 0.007 & 138 & -0.054 & 210 & -0.077 & 226 & -0.091 & 232 \\
\hline Fairbanks, AK CBSA & 0.086 & 25 & 0.094 & 42 & 0.060 & 39 & 0.065 & 35 \\
\hline Fargo-Wahpeton, ND-MN CSA & 0.012 & 128 & -0.003 & 132 & -0.003 & 107 & -0.014 & 112 \\
\hline Farmington, NM CBSA & 0.005 & 141 & 0.081 & 53 & 0.014 & 85 & 0.026 & 63 \\
\hline Fayetteville, NC CBSA & 0.076 & 31 & 0.010 & 113 & 0.071 & 26 & 0.045 & 44 \\
\hline Fayetteville-Springdale-Rogers, AR-MO CBSA & 0.030 & 95 & 0.010 & 112 & -0.020 & 133 & -0.041 & 152 \\
\hline Flagstaff, AZ CBSA & 0.029 & 97 & 0.083 & 51 & 0.105 & 7 & 0.098 & 27 \\
\hline Florence, SC CBSA* & -0.009 & 168 & -0.041 & 190 & -0.095 & 246 & -0.079 & 216 \\
\hline Florence-Muscle Shoals, AL CBSA & -0.007 & 165 & -0.070 & 232 & -0.032 & 150 & -0.036 & 142 \\
\hline Fond du Lac-Beaver Dam, WI CSA* & -0.049 & 243 & -0.007 & 135 & -0.089 & 243 & -0.027 & 128 \\
\hline Fort Collins-Loveland, CO CBSA & 0.065 & 43 & 0.088 & 47 & 0.044 & 51 & 0.041 & 50 \\
\hline Fort Smith, AR-OK CBSA & -0.003 & 158 & -0.043 & 195 & 0.012 & 90 & -0.007 & 101 \\
\hline Fort Walton Beach-Crestview-Destin, FL CBSA* & 0.129 & 6 & 0.116 & 33 & 0.116 & 6 & 0.068 & 33 \\
\hline Fort Wayne-Huntington-Auburn, IN CSA & -0.087 & 279 & -0.155 & 289 & -0.130 & 271 & -0.176 & 287 \\
\hline Fresno-Madera, CA CSA & -0.031 & 213 & 0.069 & 60 & -0.029 & 147 & -0.009 & 107 \\
\hline Gadsden, AL CBSA* & 0.050 & 60 & -0.009 & 137 & -0.063 & 199 & -0.062 & 189 \\
\hline
\end{tabular}




\begin{tabular}{|c|c|c|c|c|c|c|c|c|}
\hline Gainesville, FL CBSA & -0.048 & 242 & -0.041 & 193 & 0.058 & 41 & 0.022 & 68 \\
\hline Goldsboro, NC CBSA* & -0.006 & 163 & 0.017 & 102 & 0.024 & 69 & 0.046 & 43 \\
\hline Grand Forks, ND-MN CBSA* & -0.023 & 199 & -0.077 & 240 & 0.044 & 52 & 0.021 & 69 \\
\hline Grand Junction, CO CBSA & 0.049 & 65 & 0.093 & 44 & 0.099 & 11 & 0.121 & 17 \\
\hline Grand Rapids-Muskegon-Holland, MI CSA & -0.027 & 209 & -0.037 & 179 & -0.100 & 250 & -0.098 & 243 \\
\hline Great Falls, MT CBSA* & 0.037 & 82 & 0.073 & 59 & 0.102 & 9 & 0.141 & 12 \\
\hline Green Bay, WI CBSA & -0.061 & 255 & -0.041 & 192 & -0.143 & 281 & -0.105 & 252 \\
\hline Greensboro-Winston-Salem-High Point, NC CSA & -0.015 & 180 & -0.050 & 207 & -0.077 & 224 & -0.075 & 210 \\
\hline Greenville, NC CBSA & -0.009 & 167 & -0.040 & 189 & -0.088 & 241 & -0.069 & 198 \\
\hline Greenville-Spartanburg-Anderson, SC CSA & -0.014 & 176 & -0.040 & 186 & -0.084 & 234 & -0.096 & 240 \\
\hline Gulfport-Biloxi-Pascagoula, MS CSA & 0.050 & 62 & -0.026 & 161 & -0.002 & 106 & -0.043 & 157 \\
\hline Hagerstown-Martinsburg, MD-WV CBSA* & -0.035 & 218 & 0.014 & 105 & -0.084 & 232 & -0.071 & 204 \\
\hline Hanford-Corcoran, CA CBSA* & 0.066 & 42 & 0.134 & 24 & -0.050 & 178 & -0.071 & 202 \\
\hline Harrisburg-Carlisle-Lebanon, PA CSA* & -0.010 & 170 & -0.010 & 141 & -0.109 & 257 & -0.102 & 248 \\
\hline Harrisonburg, VA CBSA & 0.014 & 124 & 0.027 & 88 & -0.012 & 119 & 0.016 & 77 \\
\hline Hartford-West Hartford-Willimantic, CT CSA & -0.049 & 244 & 0.008 & 114 & -0.144 & 283 & -0.079 & 217 \\
\hline Hattiesburg, MS CBSA & 0.033 & 91 & -0.034 & 176 & 0.051 & 49 & 0.017 & 75 \\
\hline Hickory-Lenoir-Morganton, NC CBSA & 0.001 & 150 & -0.002 & 129 & -0.005 & 110 & -0.006 & 100 \\
\hline Honolulu, HI CBSA & 0.266 & 1 & 0.402 & 1 & 0.068 & 31 & 0.167 & 5 \\
\hline Hot Springs, AR CBSA & 0.079 & 28 & 0.033 & 80 & 0.030 & 63 & 0.037 & 54 \\
\hline Houma-Bayou Cane-Thibodaux, LA CBSA* & -0.037 & 223 & -0.069 & 230 & -0.051 & 182 & -0.078 & 214 \\
\hline Houston-Baytown-Huntsville, TX CSA & -0.116 & 289 & -0.201 & 293 & -0.143 & 280 & -0.210 & 292 \\
\hline Huntington-Ashland, WV-KY-OH CBSA* & 0.006 & 140 & -0.045 & 198 & -0.066 & 203 & -0.081 & 222 \\
\hline Huntsville-Decatur, AL CSA & -0.019 & 195 & -0.069 & 231 & -0.077 & 225 & -0.107 & 254 \\
\hline Idaho Falls-Blackfoot, ID CSA & 0.028 & 103 & 0.006 & 119 & 0.059 & 40 & 0.059 & 37 \\
\hline Indianapolis-Anderson-Columbus, IN CSA & -0.069 & 269 & -0.132 & 283 & -0.103 & 254 & -0.134 & 272 \\
\hline Iowa City, IA CBSA* & 0.029 & 98 & 0.006 & 116 & -0.004 & 109 & -0.010 & 108 \\
\hline Ithaca-Cortland, NY CSA & 0.075 & 32 & 0.024 & 92 & 0.036 & 56 & -0.005 & 97 \\
\hline Jackson, MI CBSA* & -0.016 & 183 & -0.009 & 139 & -0.128 & 269 & -0.109 & 257 \\
\hline Jackson-Humboldt, TN CSA & -0.049 & 245 & -0.115 & 278 & -0.060 & 191 & -0.075 & 209 \\
\hline Jacksonville, FL CBSA & 0.024 & 105 & 0.001 & 124 & -0.017 & 126 & -0.072 & 205 \\
\hline Jacksonville, NC CBSA* & 0.079 & 29 & 0.026 & 90 & 0.076 & 21 & 0.036 & 55 \\
\hline Jackson-Yazoo City, MS CSA & -0.020 & 196 & -0.102 & 268 & -0.085 & 237 & -0.143 & 276 \\
\hline Janesville, WI CBSA & 0.014 & 126 & 0.011 & 110 & -0.154 & 289 & -0.119 & 265 \\
\hline Jefferson City, MO CBSA & -0.045 & 234 & -0.064 & 222 & 0.007 & 94 & 0.009 & 85 \\
\hline Johnson City-Kingsport-Bristol, TN-VA CSA & -0.033 & 215 & -0.038 & 183 & -0.039 & 159 & -0.028 & 129 \\
\hline Johnstown, PA CBSA & -0.044 & 233 & -0.018 & 150 & -0.086 & 239 & -0.037 & 145 \\
\hline Jonesboro-Paragould, AR CSA & 0.029 & 99 & -0.024 & 158 & -0.008 & 112 & -0.035 & 136 \\
\hline Joplin, MO CBSA & 0.029 & 96 & -0.033 & 173 & 0.044 & 53 & 0.009 & 84 \\
\hline Kalamazoo-Portage, MI CBSA & -0.006 & 164 & -0.028 & 165 & -0.102 & 253 & -0.093 & 236 \\
\hline Kansas City-Overland Park, MO-KS CSA & -0.038 & 225 & -0.084 & 249 & -0.075 & 221 & -0.121 & 266 \\
\hline Kennewick-Pasco-Richland, WA CBSA & -0.093 & 283 & -0.105 & 269 & -0.099 & 248 & -0.115 & 262 \\
\hline Killeen-Temple-Fort Hood, TX CBSA & 0.004 & 145 & -0.059 & 218 & 0.061 & 34 & 0.020 & 70 \\
\hline Knoxville-Sevierville-La Follette, TN CSA & -0.011 & 173 & -0.032 & 171 & -0.009 & 115 & -0.001 & 93 \\
\hline Kokomo-Peru, IN CSA* & -0.168 & 293 & -0.150 & 288 & -0.223 & 292 & -0.239 & 293 \\
\hline La Crosse, WI-MN CBSA* & 0.023 & 109 & 0.027 & 86 & -0.074 & 218 & -0.013 & 111 \\
\hline Lafayette-Acadiana, LA CSA & 0.034 & 89 & -0.010 & 142 & -0.015 & 122 & -0.030 & 132 \\
\hline Lafayette-Frankfort, IN CSA & -0.003 & 159 & -0.097 & 261 & -0.054 & 185 & -0.079 & 218 \\
\hline Lake Charles-Jennings, LA CSA & -0.047 & 236 & -0.112 & 274 & -0.082 & 231 & -0.105 & 251 \\
\hline Lake Havasu City-Kingman, AZ CBSA & 0.043 & 76 & 0.131 & 25 & 0.086 & 15 & 0.102 & 24 \\
\hline Lakeland-Winter Haven, FL CBSA* & 0.020 & 117 & -0.001 & 126 & -0.003 & 108 & -0.031 & 133 \\
\hline Lancaster, PA CBSA & 0.002 & 147 & -0.003 & 130 & -0.049 & 175 & -0.035 & 135 \\
\hline Lansing-East Lansing-Owosso, MI CSA* & -0.048 & 239 & -0.081 & 246 & -0.140 & 278 & -0.161 & 284 \\
\hline Laredo, TX CBSA* & -0.018 & 192 & -0.034 & 175 & -0.046 & 168 & -0.040 & 150 \\
\hline
\end{tabular}




\begin{tabular}{|c|c|c|c|c|c|c|c|c|}
\hline Las Cruces, NM CBSA & 0.086 & 22 & 0.113 & 34 & 0.015 & 81 & 0.034 & 58 \\
\hline Las Vegas-Paradise-Pahrump, NV CSA & -0.098 & 285 & -0.094 & 260 & -0.085 & 236 & -0.153 & 281 \\
\hline Lawrence, KS CBSA & 0.058 & 49 & 0.028 & 85 & 0.035 & 58 & 0.001 & 91 \\
\hline Lawton, OK CBSA & 0.057 & 51 & -0.017 & 147 & 0.074 & 23 & 0.029 & 62 \\
\hline Lewiston, ID-WA CBSA* & 0.063 & 45 & 0.084 & 50 & 0.080 & 20 & 0.106 & 22 \\
\hline Lexington--Frankfort--Richmond, KY CSA & 0.023 & 108 & 0.006 & 117 & -0.031 & 148 & -0.053 & 174 \\
\hline Lima-Van Wert-Wapakoneta, OH CSA & 0.007 & 139 & -0.002 & 127 & -0.113 & 260 & -0.108 & 255 \\
\hline Lincoln, NE CBSA* & 0.004 & 144 & -0.020 & 154 & -0.009 & 113 & -0.015 & 11 \\
\hline Little Rock-N. Little Rock-Pine Bluff, AR CSA & 0.031 & 92 & -0.018 & 149 & -0.033 & 152 & -0.055 & 178 \\
\hline Logan, UT-ID CBSA* & 0.066 & 41 & 0.012 & 108 & 0.030 & 62 & 0.011 & 80 \\
\hline Longview, WA CBSA* & 0.047 & 68 & 0.173 & 16 & -0.055 & 186 & 0.031 & \\
\hline Longview-Marshall, TX CSA* & 0.001 & 149 & -0.035 & 178 & -0.037 & 157 & -0.064 & 192 \\
\hline Los Angeles-Long Beach-Riverside, CA CSA & 0.056 & 52 & 0.213 & 10 & -0.018 & 129 & 0.047 & 42 \\
\hline Louisville-Elizabethtown-Scotts., KY-IN CSA & -0.018 & 190 & -0.025 & 159 & -0.071 & 210 & -0.066 & 193 \\
\hline Lubbock-Levelland, TX CSA & 0.036 & 85 & -0.049 & 206 & 0.015 & 82 & -0.056 & 180 \\
\hline Lynchburg, VA CBSA* & 0.017 & 121 & 0.016 & 103 & -0.042 & 164 & -0.047 & 162 \\
\hline Macon-Warner Robins-Fort Valley, GA CSA* & -0.042 & 231 & -0.114 & 277 & -0.086 & 240 & -0.110 & 259 \\
\hline Madison-Baraboo, WI CSA* & 0.008 & 133 & 0.027 & 87 & -0.051 & 180 & -0.020 & 118 \\
\hline Mansfield-Bucyrus, OH CSA & -0.035 & 217 & -0.039 & 184 & -0.105 & 256 & -0.067 & 196 \\
\hline McAllen-Edinburg-Mission, TX CBSA & -0.047 & 237 & -0.098 & 263 & -0.062 & 195 & -0.058 & 182 \\
\hline Medford, OR CBSA* & 0.162 & 2 & 0.311 & 3 & 0.084 & 16 & 0.153 & 9 \\
\hline Memphis, TN-MS-AR CBSA & -0.068 & 267 & -0.146 & 286 & -0.150 & 286 & -0.202 & 291 \\
\hline Merced, CA CBSA* & -0.082 & 276 & 0.081 & 52 & -0.071 & 213 & -0.044 & 159 \\
\hline Miami-Ft. Lauderdale-Pomp. Beach, FL CBSA & 0.069 & 37 & 0.095 & 41 & -0.016 & 123 & -0.060 & 187 \\
\hline Midland-Odessa, TX CSA & -0.064 & 263 & -0.156 & 290 & -0.018 & 130 & -0.079 & 215 \\
\hline Milwaukee-Racine-Waukesha, WI CSA & -0.084 & 278 & -0.046 & 199 & -0.149 & 285 & -0.102 & 247 \\
\hline Minneapolis-St. Paul-St. Cloud, MN-WI CSA & -0.015 & 181 & -0.020 & 153 & -0.073 & 215 & -0.094 & 237 \\
\hline Missoula, MT CBSA & 0.089 & 18 & 0.154 & 20 & 0.195 & 2 & 0.217 & 2 \\
\hline Mobile-Daphne-Fairhope, AL CSA & 0.043 & 77 & 0.003 & 123 & -0.042 & 165 & -0.062 & \\
\hline Modesto, CA CBSA* & -0.019 & 194 & 0.097 & 39 & -0.071 & 212 & -0.070 & 200 \\
\hline Monroe-Bastrop, LA CSA* & -0.064 & 262 & -0.085 & 250 & 0.000 & 104 & -0.023 & 123 \\
\hline Montgomery-Alexander City, AL CSA & 0.023 & 110 & -0.058 & 215 & 0.000 & 100 & -0.050 & 168 \\
\hline Morgantown, WV CBSA & 0.111 & 8 & 0.066 & 62 & 0.089 & 12 & 0.009 & 82 \\
\hline Muncie, IN CBSA* & -0.060 & 253 & -0.100 & 266 & -0.068 & 206 & -0.085 & 228 \\
\hline Myrtle Beach-Conway-Georgetown, SC CSA & 0.044 & 72 & 0.048 & 71 & 0.053 & 48 & 0.038 & 52 \\
\hline Naples-Marco Island, FL CBSA* & 0.010 & 130 & 0.122 & 32 & -0.032 & 149 & 0.000 & 92 \\
\hline Nashville--Murfreesboro--Columbia, TN CSA & 0.009 & 132 & -0.024 & 157 & -0.080 & 229 & -0.100 & 246 \\
\hline New Orleans-Metairie-Bogalusa, LA CSA & 0.089 & 19 & -0.020 & 155 & -0.021 & 136 & -0.036 & 141 \\
\hline New York-Newark-Bridge., NY-NJ-CT-PA CSA & 0.018 & 120 & 0.136 & 23 & -0.048 & 173 & 0.049 & 41 \\
\hline Niles-Benton Harbor, MI CBSA* & -0.005 & 162 & 0.035 & 77 & -0.071 & 208 & -0.048 & 166 \\
\hline Norwich-New London, CT CBSA & -0.061 & 256 & 0.010 & 111 & -0.084 & 233 & -0.033 & 134 \\
\hline Ocala, FL CBSA* & 0.013 & 127 & 0.051 & 68 & 0.070 & 29 & 0.039 & 51 \\
\hline Ocean City, NJ CBSA* & -0.036 & 220 & 0.165 & 17 & -0.101 & 252 & -0.027 & 126 \\
\hline Oklahoma City-Shawnee, OK CSA & 0.007 & 137 & -0.057 & 214 & 0.003 & 96 & -0.054 & 175 \\
\hline Omaha-Council Bluffs-Fremont, NE-IA CSA & -0.026 & 207 & -0.062 & 220 & -0.075 & 220 & -0.099 & 245 \\
\hline Orlando-Deltona-Daytona Beach, FL CSA & 0.087 & 21 & 0.069 & 61 & 0.001 & 99 & -0.071 & 203 \\
\hline Owensboro, KY CBSA* & -0.124 & 291 & -0.087 & 252 & -0.047 & 171 & -0.054 & 176 \\
\hline Palm Bay-Melbourne-Titusville, FL CBSA* & 0.040 & 80 & 0.029 & 84 & 0.032 & 61 & -0.021 & 121 \\
\hline Panama City-Lynn Haven, FL CBSA* & 0.091 & 17 & 0.088 & 48 & 0.089 & 14 & 0.061 & 36 \\
\hline Parkersburg-Marietta-Vienna, WV-OH CBSA* & 0.005 & 142 & -0.040 & 187 & -0.043 & 166 & -0.043 & 156 \\
\hline Pensacola-Ferry Pass-Brent, FL CBSA* & 0.086 & 24 & 0.033 & 79 & 0.072 & 24 & 0.032 & 59 \\
\hline Peoria-Canton, IL CSA & -0.046 & 235 & -0.072 & 236 & -0.154 & 287 & -0.122 & 26 \\
\hline Philadelphia-Camden-Vine., PA-NJ-DE-MD CSA & -0.005 & 161 & -0.003 & 131 & -0.133 & 275 & -0.140 & 27 \\
\hline Phoenix-Mesa-Scottsdale, AZ CBSA & -0.026 & 208 & -0.019 & 152 & -0.020 & 131 & -0.070 & 20 \\
\hline
\end{tabular}




\begin{tabular}{|c|c|c|c|c|c|c|c|c|}
\hline Pittsburgh-New Castle, PA CSA & -0.037 & 222 & -0.059 & 217 & -0.035 & 154 & -0.012 & 109 \\
\hline Pittsfield, MA CBSA & 0.024 & 106 & 0.088 & 49 & -0.028 & 146 & 0.057 & 39 \\
\hline Pocatello, ID CBSA* & 0.031 & 93 & -0.011 & 143 & 0.054 & 46 & 0.044 & 48 \\
\hline Port St. Lucie-Sebastian-Vero Beach, FL CSA & 0.049 & 66 & 0.061 & 64 & 0.022 & 72 & 0.019 & 71 \\
\hline Portland-Lewiston-South Portland, ME CSA & 0.071 & 36 & 0.130 & 26 & 0.054 & 47 & 0.122 & 16 \\
\hline Portland-Vancouver-Beaverton, OR-WA CBSA & 0.088 & 20 & 0.157 & 19 & 0.002 & 97 & 0.037 & 53 \\
\hline Prescott, AZ CBSA & 0.072 & 35 & 0.192 & 12 & 0.196 & 1 & 0.246 & 1 \\
\hline Provo-Orem, UT CBSA* & 0.036 & 86 & 0.020 & 98 & 0.023 & 70 & -0.006 & 98 \\
\hline Pueblo, CO CBSA & -0.051 & 247 & -0.048 & 204 & 0.016 & 78 & 0.017 & 73 \\
\hline Raleigh-Durham-Cary, NC CSA & -0.025 & 205 & -0.063 & 221 & -0.061 & 193 & -0.093 & 234 \\
\hline Rapid City, SD CBSA* & 0.079 & 27 & 0.110 & 35 & 0.062 & 33 & 0.093 & 28 \\
\hline Redding, CA CBSA* & 0.044 & 75 & 0.177 & 14 & 0.055 & 44 & 0.081 & 32 \\
\hline Reno-Sparks-Fernley, NV CSA & 0.021 & 116 & 0.078 & 56 & 0.013 & 88 & 0.006 & 86 \\
\hline Richmond, VA CBSA & 0.005 & 143 & -0.008 & 136 & -0.063 & 198 & -0.081 & 220 \\
\hline Roanoke, VA CBSA & -0.051 & 248 & -0.075 & 238 & -0.046 & 167 & -0.047 & 163 \\
\hline Rochester, MN CBSA & -0.030 & 211 & -0.084 & 248 & -0.110 & 258 & -0.154 & 282 \\
\hline Rochester-Batavia-Seneca Falls, NY CSA & -0.024 & 202 & -0.054 & 211 & -0.067 & 204 & -0.087 & 230 \\
\hline Rockford-Freeport-Rochelle, IL CSA & -0.064 & 264 & -0.079 & 242 & -0.165 & 290 & -0.138 & 273 \\
\hline Rocky Mount, NC CBSA* & -0.084 & 277 & -0.088 & 254 & -0.046 & 169 & -0.042 & 154 \\
\hline Rome, GA CBSA & -0.002 & 155 & -0.038 & 181 & -0.051 & 183 & -0.051 & 173 \\
\hline Sacramento-Arcade-Yuba, CA-NV CSA & 0.020 & 118 & 0.126 & 29 & -0.012 & 120 & 0.015 & 78 \\
\hline Saginaw-Bay City-Saginaw Twp. N., MI CSA* & -0.049 & 246 & -0.072 & 234 & -0.154 & 288 & -0.147 & 278 \\
\hline Salem, OR CBSA* & 0.068 & 39 & 0.126 & 30 & 0.023 & 71 & 0.066 & 34 \\
\hline Salinas, CA CBSA* & 0.075 & 33 & 0.268 & 6 & 0.018 & 75 & 0.169 & 3 \\
\hline Salisbury-Ocean Pines, MD CSA* & -0.076 & 274 & -0.028 & 164 & -0.036 & 155 & -0.028 & 130 \\
\hline Salt Lake City-Ogden-Clearfield, UT CSA & 0.048 & 67 & 0.022 & 97 & 0.008 & 93 & -0.019 & 117 \\
\hline San Angelo, TX CBSA & 0.035 & 87 & -0.043 & 194 & 0.044 & 54 & -0.007 & 104 \\
\hline San Antonio, TX CBSA & -0.010 & 171 & -0.067 & 227 & -0.063 & 201 & -0.119 & 264 \\
\hline San Diego-Carlsbad-San Marcos, CA CBSA & 0.086 & 23 & 0.237 & 9 & 0.075 & 22 & 0.142 & 11 \\
\hline San Jose-San Francisco-Oakland, CA CSA & 0.067 & 40 & 0.273 & 5 & 0.014 & 86 & 0.160 & 6 \\
\hline San Luis Obispo-Paso Robles, CA CBSA* & 0.106 & 11 & 0.303 & 4 & 0.055 & 45 & 0.157 & 8 \\
\hline Santa Barbara-Santa Maria-Goleta, CA CBSA* & 0.156 & 3 & 0.323 & 2 & 0.072 & 25 & 0.169 & 4 \\
\hline Santa Fe-Espanola, NM CSA* & 0.023 & 111 & 0.079 & 54 & 0.034 & 60 & 0.100 & 26 \\
\hline Sarasota-Bradenton-Punta Gorda, FL CSA & 0.081 & 26 & 0.109 & 36 & 0.060 & 37 & 0.044 & 46 \\
\hline Savannah-Hinesville-Fort Stewart, GA CSA & -0.015 & 179 & -0.041 & 191 & -0.052 & 184 & -0.069 & 199 \\
\hline Scranton--Wilkes-Barre, PA CBSA* & 0.000 & 153 & 0.003 & 122 & -0.073 & 216 & -0.042 & 153 \\
\hline Seattle-Tacoma-Olympia, WA CSA & 0.000 & 151 & 0.093 & 46 & -0.022 & 138 & 0.017 & 74 \\
\hline Sheboygan, WI CBSA & 0.024 & 107 & 0.057 & 66 & -0.137 & 276 & -0.076 & 212 \\
\hline Shreveport-Bossier City-Minden, LA CSA & -0.024 & 203 & -0.081 & 245 & -0.073 & 217 & -0.128 & 270 \\
\hline Sioux City-Vermillion, IA-NE-SD CSA & -0.051 & 249 & -0.092 & 258 & -0.026 & 141 & -0.048 & 165 \\
\hline Sioux Falls, SD CBSA* & 0.040 & 79 & 0.013 & 106 & 0.015 & 80 & 0.004 & 88 \\
\hline South Bend-Elkhart-Mishawaka, IN-MI CSA & -0.080 & 275 & -0.141 & 284 & -0.129 & 270 & -0.158 & 283 \\
\hline Spokane, WA CBSA & 0.049 & 64 & 0.053 & 67 & 0.029 & 64 & 0.026 & 65 \\
\hline Springfield, IL CBSA & -0.060 & 254 & -0.119 & 279 & -0.118 & 263 & -0.125 & 269 \\
\hline Springfield, MA CBSA* & -0.058 & 252 & 0.024 & 93 & -0.039 & 160 & 0.044 & 47 \\
\hline Springfield, MO CBSA & 0.050 & 61 & 0.019 & 100 & 0.040 & 55 & 0.016 & 76 \\
\hline St. George, UT CBSA & 0.094 & 15 & 0.094 & 43 & 0.157 & 3 & 0.159 & 7 \\
\hline St. Joseph, MO-KS CBSA & -0.001 & 154 & -0.047 & 201 & -0.017 & 127 & -0.050 & 169 \\
\hline St. Louis-St. Charles-Farmington, MO-IL CSA & -0.076 & 273 & -0.107 & 271 & -0.132 & 272 & -0.147 & 279 \\
\hline State College, PA CBSA* & 0.143 & 5 & 0.126 & 31 & 0.070 & 27 & 0.050 & 40 \\
\hline Stockton, CA CBSA* & -0.021 & 197 & 0.102 & 37 & -0.101 & 251 & -0.083 & 224 \\
\hline Sumter, SC CBSA & -0.061 & 258 & -0.106 & 270 & 0.016 & 77 & -0.007 & 102 \\
\hline Syracuse-Auburn, NY CSA & -0.019 & 193 & -0.047 & 203 & -0.094 & 245 & -0.085 & 226 \\
\hline Tallahassee, FL CBSA* & 0.056 & 54 & 0.036 & 76 & 0.060 & 38 & 0.036 & 56 \\
\hline
\end{tabular}




\begin{tabular}{|c|c|c|c|c|c|c|c|c|}
\hline Tampa-St. Petersburg-Clearwater, FL CBSA & 0.033 & 90 & 0.018 & 101 & 0.014 & 87 & -0.047 & 164 \\
\hline Terre Haute, IN CBSA & -0.070 & 270 & -0.099 & 265 & -0.038 & 158 & -0.046 & 161 \\
\hline Texarkana, TX-Texarkana, AR CBSA* & -0.018 & 191 & -0.072 & 235 & -0.047 & 172 & -0.079 & 219 \\
\hline Toledo-Fremont, $\mathrm{OH} \mathrm{CSA} *$ & -0.113 & 288 & -0.113 & 276 & -0.126 & 268 & -0.103 & 250 \\
\hline Topeka, KS CBSA & -0.030 & 212 & -0.088 & 253 & -0.041 & 163 & -0.093 & 235 \\
\hline Tucson, AZ CBSA & 0.054 & 55 & 0.078 & 55 & 0.024 & 68 & 0.041 & 49 \\
\hline Tulsa-Bartlesville, OK CSA & 0.044 & 73 & -0.013 & 146 & 0.014 & 84 & -0.041 & 151 \\
\hline Tuscaloosa, AL CBSA & -0.021 & 198 & -0.053 & 208 & -0.015 & 121 & -0.037 & 144 \\
\hline Tyler-Jacksonville, TX CSA & -0.010 & 169 & -0.076 & 239 & -0.046 & 170 & -0.095 & 239 \\
\hline Utica-Rome, NY CBSA* & -0.029 & 210 & -0.067 & 228 & -0.073 & 214 & -0.073 & 207 \\
\hline Valdosta, GA CBSA & 0.018 & 119 & -0.030 & 167 & 0.005 & 95 & -0.008 & 106 \\
\hline Victoria, TX CBSA & -0.035 & 219 & -0.092 & 257 & -0.140 & 279 & -0.176 & 286 \\
\hline Virg. Beach-Norfolk-Newp. News, VA-NC CBSA & 0.017 & 122 & 0.012 & 109 & 0.000 & 103 & -0.017 & 116 \\
\hline Visalia-Porterville, CA CBSA* & -0.041 & 230 & 0.050 & 69 & -0.027 & 142 & -0.001 & 94 \\
\hline Waco, TX CBSA & -0.063 & 260 & -0.142 & 285 & -0.041 & 162 & -0.076 & 211 \\
\hline Washington-Balt.-N. VA, DC-MD-VA-WV CSA & -0.017 & 187 & 0.004 & 120 & -0.078 & 228 & -0.109 & 258 \\
\hline Waterloo-Cedar Falls, IA CBSA & 0.046 & 69 & 0.025 & 91 & 0.018 & 74 & 0.026 & 64 \\
\hline Wausau-Merrill, WI CSA & -0.087 & 280 & -0.074 & 237 & -0.067 & 205 & -0.061 & 188 \\
\hline Weirton-Steubenville, WV-OH CBSA* & -0.048 & 240 & -0.035 & 177 & -0.059 & 190 & -0.058 & 183 \\
\hline Wenatchee, WA CBSA* & -0.014 & 177 & 0.129 & 28 & 0.035 & 59 & 0.089 & 30 \\
\hline Wheeling, WV-OH CBSA* & 0.045 & 71 & -0.038 & 180 & -0.056 & 187 & -0.054 & 177 \\
\hline Wichita Falls, TX CBSA* & 0.008 & 134 & -0.125 & 280 & 0.016 & 79 & -0.040 & 148 \\
\hline Wichita-Winfield, KS CSA & -0.002 & 156 & -0.057 & 213 & -0.049 & 176 & -0.098 & 244 \\
\hline Williamsport-Lock Haven, PA CSA* & 0.064 & 44 & 0.049 & 70 & -0.020 & 134 & 0.014 & 79 \\
\hline Wilmington, NC CBSA & 0.037 & 83 & 0.064 & 63 & 0.024 & 67 & 0.034 & 57 \\
\hline Yakima, WA CBSA* & -0.016 & 186 & 0.034 & 78 & -0.051 & 181 & -0.014 & 113 \\
\hline York-Hanover-Gettysburg, PA CSA & -0.066 & 265 & -0.067 & 225 & -0.085 & 238 & -0.067 & 194 \\
\hline Youngstown-Warren-East Liverpool, OH-PA CSA & -0.073 & 272 & -0.099 & 264 & -0.144 & 282 & -0.125 & 268 \\
\hline Yuma, AZ CBSA & 0.078 & 30 & 0.073 & 58 & -0.012 & 118 & 0.019 & 72 \\
\hline
\end{tabular}

* Indicates that non-housing prices are imputed for the CBSA/CSA. 